\title{
PENGEMBANGAN BAHAN AJAR KOMIK IPA DENGAN PENANAMAN NILAI BUDAI PADA SISWA KELAS IV SEKOLAH DASAR
}

\author{
Yunita Sari \\ Fakultas Keguruan dan Ilmu Pendidikan, Program Studi Pendidikan Guru Sekolah \\ Dasar Universitas Islam Sultan Agung Semarang \\ Email : gitarasya7@gmail.com
}

\begin{abstract}
Abstrak
Masalah yang sering dihadapi pada anak sekolah dasar dalam pembelajaran ilmu pengetahuan alam adalah penggunaan media pembelajaran yang kurang menarik bagi siswa dan siswa kesulitan memahami materi yang disajikan dalam bahan ajar IPA yang digunakan di sekolah. Media yang ada sifatnya yang terbatas membuat siswa malas belajar.Tujuan Penelitian ini adalah untuk mendapatkan gambaran karakteristik, kevalidan, keefektifan, dan kepraktisan produk bahan ajar komik yang dikembangkan dalam pembelajaran IPA materi Bagian-bagian tumbuhan di kelas IV Sekolah Dasar. Subjek uji coba pada penelitian pengembangan ini adalah kelas IV SDN Beji 03 dengan peserta didik sejumlah 21 siswa. Desain uji coba produk yang digunakan dalam pengembangan bahan ajar komik IPA adalah PretestPosttest Control Group Design. Jenis penelitian pengembangan ini dengan menggunakan model Borg and Gall. Perangkat yang dikembangkan meliputi: Silabus, Rencana Pelaksanaan Pembelajaran, Komik Ilmu Pengetahuan Alam, dan Tes Prestasi Belajar Materi Bagian-bagian tumbuhan. Data diperoleh melalui lembar pengamatan dan tes prestasi belajar materi bagian-bagian tumbuhan. Hasilnya diolah secara deskriptif, menggunakan uji ketuntasan, uji banding dan uji peningkatan untuk mengetahui efektivitas pembelajaran. Hasil uji tebatas menunjukkan persentase skor respon siswa $84,6 \%$, rata-rata respon guru 3,5 skor pengamatan kemampuan guru mengelola pembelajaran pertemuan I dan II 2,5 dan 3,0 sehingga termasuk kategori praktis. Implementasi perangkat ini menghasilkan (1) nilai rata-rata tes prestasi belajar kelas eksperimen 81,52 dari Kriteria ketuntasan minimal 75, (2) rata-rata nilai kelas eksperimen yaitu 81,52 lebih baik dari rata-rata nilai kelas kontrol sebesar 56,80 (3) uji peningkatan tes prestasi belajar kelas eksperimen yaitu 0,565 dan peningkatan kelas kontrol 0,404. Dari hasil penelitian dapat disimpulkan bahwa bahan ajar komik IPA layak digunakan dalam pembelajaran, selain itu penerapan bahan ajar komik IPA dapat meningkatkan prestasi belajar peserta didik.
\end{abstract}

Kata Kunci : bahan ajar komik IPA, nilai-nilai budai, prestasi belajar, valid, praktis, efektif.

\section{PENDAHULUAN}

Bahan ajar merupakan segala

bahan baik informasi,alat,maupun teks

yang disusun secara sistematis,yang menampilkan sosok utuh dari kompetensi yang akan digunakan peserta didik dan digunakan dalam proses pembelajaran dengan tujuan 
perencanaan dan penelaah implementasi pembelajaran. Menurut National Centre for Competency Based Training (2007) bahan ajar merupakan segala bentuk bahan yang digunakan untuk membantu guru atau instruktur dalam melaksanakan proses pembelajaran di kelas. Bahan ajar bisa berupa bahan tertulis maupun bahan tidak tertulis.

Pannen (2001) mengungkapkan bahwa bahan ajar adalah bahan-bahan atau materi pelajaran yang disusun secara sistematis, yang digunakan guru dan peserta didik dalam proses pembelajaran. Komik dapat didefinisikan sebagai suatu bentuk kartun yang mengungkapkan karakter dan memerankan suatu cerita dalam urutan yang erat dihubungkan dengan gambar dan dirancang untuk memberikan hiburan kepada para pembaca, sekumpulan gambar-gambar yang disusun dalam sebuah atau beberapa buah panil kotak dalam satu bidang menjadi suatu jalinan cerita (Sudjana, 2010:64).

$$
\text { Hariyanto }
$$

menyatakan pendidikan karakter dimaknai sebagai cara berfikir dan berperilaku yang khas tiap individu untuk hidup dan bekerja sama, baik dalam lingkup keluarga, masyarakat, bangsa, dan negara. Karakter merupakan nilai - nikai yang unik baik yang terpatri dalam diri dan terejawantahkan dalam perilaku (Kementrian Pendidikan Nasional, 2010). Scerenco (1997) mendifinisikan karakter sebagai atribut atau ciri-ciri yang membentuk dan membedakan ciri pribadi, ciri etnis, dan kompleksitas mental dari seseorang, suatu kelompok atau bangsa.

Berdasarkan hasil field studi di SDN Beji 03 Kabupaten Batang pembelajaran di sekolah masih didominasi aspek kognitif kurang membentuk karakter siswa. Penanaman nilai religius belum menyentuh pada mata pelajaran lain selain agama. Melalui penanaman nilai religius diharapkan bisa menjadi tameng bagi siswa terhadap karakterkarakter negatif, dimana nilai religius merupakan dasar untuk penanaman nilai-nilai positif yang lain.

Oleh karena itu untuk melahirkan generasi yang tidak hanya berilmu tinggi tetapi juga bertaqwa dan berjamaah perlu diterapkan pembelajaran berbasis Budaya Akademik Islam (BudAI) di SDN Beji 
03 Kabupaten Batang yang didukung $100 \%$ guru, karyawan, dan siswa beragama Islam. Penerapan BudAI merupakan salah satu wujud pendidikan karakter. BudAI pada intinya berisi penguatan ruhiyah dan penguatan Iptek. Adapun penguatan ruhiyah adalah penguatan akidah, ibadah, dan akhlak yang dikemas dalam gerakan pembudayaan yang meliputi gerakan shalat berjama'ah, gerakan berbusana Islami, gerakan thaharah, gerakan keteladanan, gerakan keramahan Islami, dan gerakan kualitas hidup. Sedangkan penguatan Iptek terdiri atas semangat iqra', mengembangkan Iptek atas dasar nilai-nilai Islam, Islamic Learning Society, dan apresiasi Iptek (Unissula, 2005).

Pembelajaran berbasis BudAI dalam penelitian ini difokuskan pada pembelajaran IPA. Sesuai Permendiknas No. 22 Tahun 2006 tujuan mata pelajaran tidak hanya pada pengusaan bidang ilmu tetapi juga meliki komitmen dan kesadaran terhadap nilai-nilai sosial dan kemanusiaan (Kemendiknas, 2006). Sehingga implementasi BudAI dalam penelitian ini tidak hanya melalui pembiasaan terkait nilai atau karakter religius juga didukung dengan memasukkan materi nilai-nilai Islam dalam pembelajaran IPA.

Masalah yang sering dihadapi pada anak sekolah dasar dalam pembelajaran ilmu pengetahuan alam adalah penggunaan media pembelajaran yang kurang menarik bagi siswa dan dalam pembelajaran tidak selalu menggunakan media. Media yang ada sifatnya yang terbatas membuat siswa malas belajar. Penggunaan bahan ajar yang kurang menarik dan terbatas membuat siswa malas membaca. Dalam proses pembelajaran bayak siswa yang menganggap bahwa Ilmu Pengetahuan Alam adalah mata pelajaran yang harus dihafal.

Supartono (2007) menyatakan pendidikan di Sekolah Dasar terdiri dari beberapa mata pelajaran, salah satunya adalah Ilmu Pengetahuan Alam (IPA). IPA dapat dipandang dari segi produk, proses dan dari segi pengembangan sikap artinya belajar IPA memiliki dimensi proses, dimensi hasil (produk) dan dimensi sikap ilmiah. Ketiga dimensi tersebut bersifat saling terkait. Ini berarti bahwa proses belajar mengajar IPA harus mampu menyediakan 
pembelajaran IPA dengan memenuhi ketiga dimensi IPA tersebut, guru juga harus mampu merancang pembelajaran IPA dengan bahan ajar, media, perangkat, metode dan strategi pembelajaran yang berperan penting dalam pendidikan anak menjadi paket pembelajaran yang menarik bagi anak mengingat bahwa anak-anak sangat menyukai hal-hal yang menarik terutama pada anak usia Sekolah Dasar.

Siswa Sekolah Dasar khususnya siswa kelas tinggi (kelas IV,V, dan VI) merupakan siswa dalam usia masa kritis dalam pertumbuhan dan perkembangan pola pikirnya. Kegiatan pembelajaran dalam hal ini pembelajaran ilmu pengetahuan alam di sekolah dasar kelas tinggi dituntut untuk bisa menarik, menimbulkan antusias, dan tidak membosankan. Pada umumnya seorang guru malas untuk membuat bahan ajar inovatif. Guru hanya mengandalkan fasilitas yang ada disekolah. Bahan ajar harus sesuai dengan minat tingkat usia anak yang berkisar antara 9-11 tahun. Pada kondisi usia ini anak sangat tertarik akan cerita bergambar.

Pembelajaran sebaiknya disajikan dengan menggunakan sebuah pembelajaran yang memiliki daya tarik bagi anak dan menggunakan pendekatan yang dapat memunculkan ketiga dimensi IPA, hal ini dapat dilakukan dengan menerapkan hal-hal yang dekat dan disukai siswa, salah satunya dengan menggunakan bahan ajar komik.

Komik merupakan bahan ajar yang unik, yang menghubungkan teks dan gambar dalam bentuk kreatif. Komik adalah media yang sanggup menarik semua perhatian semua orang dari segala usia, terutama anak-anak karena memiliki daya kelebihan yaitu menarik dan mudah dipahami. Komik dapat dijadikan sebagai bahan ajar di kelas sekolah dasar tingkat tinggi karena bentuknya yang dapat menarik perhatian siswa. komik berisa cerita dan gambar. Hal ini sangat cocok dengan kegemaran siswa sekolah dasar tingkat tinggi yang suka akan cerita dan gambar. Komik akan digunakan sebagai bahan ajar untuk siswa kelas IV sekolah dasar.

Karakter adalah nilai-nilai yang melandasi perilaku manusia berdasarkan norma agama, kebudayaan, hukum/konstitusi, adat istiadat, dan estetika. Pendidikan karakter (Kemendiknas, 2010) 
bertujuan untuk meningkatkan mutu penyelenggaraan dan hasil pendidikan di sekolah yang mengarah pada pencapaian pembentukan karakter dan akhlak mulia. Melalui pendidikan karakter diharapkan peserta didik sekolah dasar mampu secara mandiri meningkatkan dan menggunakan pengetahuannya, mengkaji dan menginternalisasi serta mempersonalisasi nilai-nilai karakter dan akhlak mulia sehigga terwujud dalam perilaku sehari-hari. Pembelajaran berbasis BudAI diharapkan terbentuk warga sekolah yang senantiasa menunjang tinggi nilai-nilai Islam, dan menjadikan Islam sebagai pandangan hidup segenap civitas akademika, menjadi sumber inspirasi, motivasi, sekaligus menjadi filter dalam kegiatan ilmiah dan budaya. Nilai-nilai religius dalam BudAI juga diharapkan menjadi vaksin bagi siswa agar tidak terpengaruh untuk melakukan sikapsikap yang melenceng yang bisa merusak masa depannya.

\section{METODE PENELITIAN}

Penelitian ini merupakan penelitian pengembangan atau Research and Development ( $\mathrm{R}$ and $\mathrm{D})$. Pada penelitian ini digunakan jenis penelitian pengembangan untuk menghasilkan produk bahan ajar. Bahan ajar yang dikembangkan adalah bahan ajar komik ipa untuk siswa kelas IV sekolah dasar. Perangkat pembelajaran yang dikembangkan meliputi silabus, RPP, bahan ajar komik IPA, dan tes prestasi belajar. Penelitian ini menggunakan desian model pengembangan perangkat pembelajaran pengembangan dengan menggunakan model Borg and Gall dengan tahap, yaitu: (1) analisis teoretis dan praktis, (2) analisis kebutuhan pengembangan bahan ajar komik, (3) penyusunan prototipe, (4) uji ahli, (5) revisi prototype, (6) uji penggunaan produk, dan (7) uji penggunaan.

Penelitian pengembangan ini dilaksanakan di SD Negeri Beji 03 Kelas IV semester 2 yang berlokasi di Jalan Raya Beji Gang Rajawali Kecamatan Tulis Kabupaten Batang. Subjek uji coba adalah siswa sekolah dasar sebanyak 21 siswa dengan lakilaki sebanyak 12 orang dan siswa perempuan sebanyak 8 orang. Dalam uji coba skala kecil siswa akan diminta untuk memberikan respon terhadap perangkat pembelajaran yang telah disimulasikan. Teknik pengambilan 
sampel dalam penelitian ini dengan Cluster Random sampling yaitu pengambilan sampel dari anggota populasi dengan menggunakan acak tanpa memperhatikan strata dari populasi itu atau disebut pengambilan sampel acak dalam cluster (tingkatan) dalam populasi tersebut (Riduwan, 2010: 12).

Analisis data validasi ahli dan praktisi menggunakan rata-rata untuk memperoleh kevalidan perangkat pembelajaran sebelum diimplementasikan. Analisis keefektifan menggunakan uji ketuntasan rata-rata, uji proporsi, uji banding, dan uji ternormalisasi gain. Uji ketuntasan rata-rata untuk mengetahui pencapain kriteria Ketuntasan Minimal (KKM) yang telah ditentukan yaitu sebesar 75 . Uji proporsi untuk mengetahui pencapaian minimal $80 \%$ siswa mendapat nilai tes prestasi belajar minimal 75 . Uji beda rata-rata untuk membandingkan prestasi belajar siswa yang diajarkan dengan perangkat yang dikembangkan dengan siswa yang diajarkan dengan siswa yang diajar tanpa perangkat yang dikembangkan. Uji normalitas dan homogenitas dilakukan sebagai uji prasyarat. Untuk mengetahui peningkatan prestasi belajar siswa kelas eksperimen dengan berdasarkan nilai before-after, dihitung dengan menggunakan rumus ternormalisasi gain (g) (Hake, 1998).

\section{HASIL PENELITIAN DAN PEMBAHASAN}

Berdasarkan rekapitulasi hasil validasi perangkat pembelajaran diperoleh rata-rata silabus 4,1 dan termasuk pada kriteria sangat valid, hasil validasi perangkat pembelajaran RPP oleh validator selama 5 kali pertemuan termasuk kriteria valid dengan nilai rata-rata RPP pertama $=$ 3,2, RPP pertemauan kedua $=3,1$, RPP pertemuan ketiga $=3,2$, RPP pertemuan keempat $=3,0$, dan RPP pertemuan kelima $=3,6$, nilai rata-rata hasil validasi untuk tes prestasi belajar materi bagian-bagian tumbuhan adalah 3,2 termasuk katagori valid, nilai ratarata hasil validasi untuk bahan ajar komik yang divalidasi oleh validator ahli komik adalah sebesar 2,8 termasuk katagori valid, dan nilai ratarata hasil validasi untuk instrumen nilai karkater yang divalidasi oleh 3 validator ahli adalah sebesar 3,2.

Revisi dilakukan berdasarkan saran para ahli. Selama proses validasi tidak banyak komentar dan saran dari 
validator. Berdasarkan hasil revisi tersebut kemudian dapat disusun prototipe perangkat dan instrumen pembelajaran yaitu, silabus, rencana pelaksanaan pembelajaran, bahan ajar komik IPA untuk siswa kelas IV Sekolah Dasar. Uji validitas butir soal dilakukan dengan menggunakan rumus korelasi product moment. Berdasarkan hasil analisis dari 30 soal terdapat 25 soal valid dan 5 soal tidak valid. Soal-soal yang valid tersebut digunakan sebagai soal uji coba lapangan untuk melihat prestasi belajar siswa yang diajarkan dengan perangkat pembelajaran yang dikembangkan. Koefisien reliabilitas suatu tes bentuk pilihan ganda dapat ditaksir dengan menggunakan rumus Alpha. Berdasarkan hasil uji reliabilitas 30 butir soal diperoleh hasil $r_{11}=0,831$, maka ditafsirkan bahwa butir soal materi pesawat bagian-bagian tumbuhan adalah reliabel yang mempunyai derajat reliabilitas tinggi. Besarnya indeks kesukaran antara 0,00 sampai dengan 1,00. Berdasarkan hasil perhitungan tingkat kesukaran dari 30 soal TPB materi bagian-bagian tumbuhan diperoleh 7 soal termasuk kriteria sedang dan 23 soal termasuk kriteria mudah.

Untuk mengetahui tanggapan siswa terhadap perangkat pembelajaran yang dikembangkan dan untuk mengetahui taggapan siswa selama proses pembelajaran dengan menggunakan komik IPA, maka siswa diminta untuk mengisi angket. Persentase skor rata-rata respon siswa adalah $84,6 \%$ dan termasuk pada kategori baik, artinya dapat dikatakan bahwa respon siswa adalah positif. Berdasarkan hasil pengamatan selama pembelajaran yaitu pada pertemuan pertama dengan nilai rata-rata kemampuan guru mengelola pembelajarana sebesar 2,5 yaitu termasuk katagori cukup baik. Pada pertemuan kedua terjadi peningkatan kemampuan guru mengelola pembelajaran dengan nilai rata-rata sebesar 3,0 yaitu termasuk katagori baik. Skor rata-rata respon 2 orang guru pada uji coba skala kecil adalah 3,5 dan termasuk pada kategori baik, artinya dapat dikatakan bahwa respon guru terhadap perangkat yang dikembangkan adalah positif.

Hasil uji normalitas kelas eksperimen dengan nilai sig 0,014 dan kelas kontrol adalah 0,011 berdistribusi 
normal. Berdasarkan uji homogenitas kedua kelas berasal dari kelas yang homogen dengan nilai sig $=0,084$. Uji ketuntasan rata-rata dengan nilai $t_{\text {hitung }}$ $=4,68$ lebih besar jika dibandingkan dengan nilai $t_{\text {tabel }}=1,725$ jadi $\mathrm{H} 1$ diterima sehingga prestasi belajar sudah memenuhi KKM. Artinya prestasi belajar IPA siswa kelas eksperimen lebih tinggi dari rata-rata yang ditetapkan yakni sebesar 75. Uji proporsi dengan nilai $z_{\text {hit }}=$ 1,64 lebih besar jika dibandingkan dengan $\mathbf{z}_{0,05}=0,17$ maka $\mathrm{H} 1$ diterima sehingga nilai kelas eksperimen sudah mencapai ketuntasan $75 \%$.

Hasil analisis uji bandingkan dengan nilai t tabel pada $\alpha=0,05$ dan $\mathrm{dk}=\mathbf{n}_{\mathbf{1}}+\mathbf{n}_{\mathbf{2}}-\mathbf{2}=21+20-2=39$, yaitu $\mathrm{t}_{0,05 ; 82}=2,00$ diperoleh $\mathrm{t}_{\text {hitung }}=$ $8,47>\mathrm{t}_{\text {tabel }}=2,00 . \quad$ Karena $\mathrm{t}_{\text {hitung }}=$ $8,47>\mathrm{t}_{\text {tabel }}=2,00$, berdasarkan kriteria penerimaan dan penolakan hipotesis maka $\mathrm{H}_{0}$ ditolak. Artinya artinya prestasi belajar IPA siswa kelas eksperimen lebih baik dari prestasi belajar IPA kelas kontrol. Hal tersebut didukung dengan perolehan rata-rata prestasi belajar IPA siswa kelas eksperimen yaitu 81,52 yang lebih besar dari rata-rata prestasi belajar IPA siswa kelas kontrol yakni 57,52.
Peningkatan prestasi belajar IPA siswa dalam penelitian ini dianalisis berdasarkan rata-rata nilai Gain yang dinormalisasi. Untuk melakukan uji Normalitas Gain, data yang digunakan adalah data pretes (tes awal) dan posttes (tes akhir) dengan menggunakan rumus Gain ternormalisasi $(g)$. Hasil analisis uji peningkatan kelas eksperimen diperoleh nilai rata-rata yaitu 0,565 , artinya peningkatan prestasi belajar IPA siswa kelas eksperimen berada pada kategori sedang dan hasil analisis uji peningkatankelas kontrol diperoleh nilai rata-rata yaitu 0,404 , artinya peningkatan prestasi belajar IPA siswa kelas kontrol berada pada kategori rendah. Berdasarkan kriteria peningkatan Gain, tes prestasi belajar IPA siswa dikatakan meningkat, jika kriterian nilai Gain berada pada kategori minimal sedang.

Pada penelitian ini juga terjadi peningkatan prestasi belajar IPAyang dianalisis menggunakan Gain ternormalkan. Untuk melakukan uji ini, data yang digunakan adalah data pretes (tes awal) dan posttes (tes akhir) dengan menggunakan rumus Gain ternormalisasi $(g)$. Hasil analisis uji peningkatan kelas eksperimen 
diperoleh nilai rata-rata yaitu 0,565 , artinya peningkatan prestasi belajar IPA siswa kelas eksperimen berada pada kategori sedang dan hasil analisis uji peningkatankelas kontrol diperoleh nilai rata-rata yaitu 0,404 , artinya peningkatan prestasi belajar IPA siswa kelas kontrol berada pada kategori rendah. Berdasarkan kriteria peningkatan Gain, tes prestasi belajar IPA siswa dikatakan meningkat, jika kriterian nilai Gain berada pada kategori minimal sedang.

Berdasarkan hasil analisis ketuntasan belajar, perbandingan prestasi belajar IPA siswa kelas eksperimen dan kontrol, dan peningkatan prestasi belajar siswa menunjukkan bahwa bahan ajar komik IPA yang dikembangkan dalam penelitian ini memberikan pengaruh terhadap prestasi belajar siswa di kelas eksperimen. Hal ini sesuai dengan hasil penelitian Song (2008) yang menyatakan bahwa komik dapat digunakan sebagai bahan pembelajaran yang kuat untuk menginterpretasikan pengetahuan dan penerapan sains. Prestasi belajar dapat meningkat karena penggunaan bahan ajar komik melatih siswa untuk tidak hanya menerima sebuah materi tetapi mampu menemukan sendiri konsepkonsep IPA melalui membaca dan mengikuti alur cerita yang terdapat dalam komik.

Hal senada juga dikemukakan oleh Rota \& Izquierdo (2003) bahwa penggunaan komik dalam pembelajaran dapat memperkuat konstruksi pemahaman konsep materi yang dipelajari oleh siswa. Berkaitan dengan hal tersebut Sudjana (2005) menyatakan bahwa mengapa media pengajaran komik dapat mempertinggi proses dan hasil pengajaran karena berkenaan dengan taraf berpikir siswa. Taraf berpikir manusia mengikuti tahap perkembangan dimulai dari berpikir kongkrit menuju ke berpikir abstrak, dimulai dari berpikir sederhana menuju ke berpikir kompleks. Penggunaan media pembelajaran erat kaitannya dengan tahapan berpikir tersebut sebab melalui media pengajaran hal-hal yang abstrak dapat dikonkretkan, dan halhal yang komplek dapat disederhanakan.

Peningkatan nilai karkater siswa terjadi disetiap pertemuan, pada pertemuan pertama katagori perkembangan bilai karakter siswa didominasi oleh katagori mulai terlihat 
(MT) dan pada pertemuan pertama katagori membudaya belum terlihat pada siswa, katagori membudaya mulai terlihat pada nilai karakter membaca juz amma. Pada pertemuan kedua terjadi penurunan nilai karakter siswa, hal ini dapat dilihat dalam pertemuan kedua dari 5 nilai karakter tidak ada siswa yang termasuk katagori membudaya (MB). Katagori membudaya pada pertemuan ketiga sampai pertemuan ke 5 sudah mulai terlihat pada setiap nilai karakter. Menurut (Koesoemo, 2007) penanaman nilai-nilai karakter melalui pendidikan di sekolah memiliki peran yang sangat strategis. Untuk menanamkan nilai-nilai karakter tersebut guru harus memiliki cara-cara dalam bertindak, diantaranya guru harus mampu sebagai pengasuh, teladan maupun pembimbing, serta guru harus mampu menggali isi materi pembelajaran yang sangat kaya dengan nilai-nilai islam.

Memperhatikan penjelasan halhal yang harus dilakukan oleh guru tersebut, dapat diterima bahwa dengan memberikan bahan ajar komik yang berisi muatan materi dan penanaman nilai BudaI memberikan pengaruh terhadap penanaman nilai karakter pada siswa. Mengingat untuk memberikan bimbingan guru tidak hanya dengan cara bertemu secara fisik dengan siswa, akan tetapi dengan instrumen tertentu salah satunya adalah bahan ajar berbentuk komik. Hal senada juga dikemukakan oleh Santana \& Arroio (2012) bahwa komik membantu kita untuk mengajarkan norma-norma dalam lingkungan masyarakat melalui akal sehat berdasarkan visualisasi dan bahasa.

\section{PENUTUP}

Perangkat pembelajaran yang dikembangkan yaitu bahan ajar komik IPA untuk siswa kelas IV Sekolah Dasar valid. Validnya perangkat pembelajaran yang telah dikembangkan didukung oleh data hasil penelitian sebagai berikut: (1) Silabus yang merupakan salah satu perangkat pembelajaran yang dikembangkan adalah valid menurut para ahli dan praktisi dengan nilai rata-rata 4,1 dari nilai maksimum 4 dengan kategori sanagt valid, (2) Rencana pelaksanaan pembelajaran (RPP) yang dikembangkan dan divalidasi setiap pertemuan valid menurut para ahli dengan nilai ratarata 3,2 dari nilai maksimum 4 dengan 
kategori valid (3) TPB materi bagianbagian tumbuhan yang dikembangkan valid menurut para ahli dengan nilai rata-rata 3,2 dari nilai maksimum 4 dengan kategori valid, (4) bahan ajar komik IPA yang dikembangkan valid menurut para ahli dengan nilai ratarata 2,8 dari nilai maksimum 3 dengan kategori valid, serta (5) angket karakter yang dikembangkan valid menurut para ahli dengan nilai ratarata 3,2 dari nilai maksimum 4 dengan kategori valid.

Implementasi bahan ajar komik IPA bermuatan nilai karkater adalah praktis, karena memenuhi kriteria: (1) skor angket kemampuan guru mengelola pembelajaran dengan menggunakan perangkat yang dikembangkan adalah 2,5 pada pertemuan pertama dan 3,0 pada pertemuan keduasehingga memenuhi kriteria respon guru positif dan (2) skor respon siswa adalah 3,78 yang membuktikan bahwa respon siswa adalah positif. Pembelajaran dengan menerapkan bahan ajar komik IPA kelas IV sekolah Dasar adalah efektif, karena memenuhi kriteria: (1) diperolehnya skor prestasi belajar siswa yang melampaui nilai KKM 75 dan lebih dari $80 \%$ dari seluruh siswa di kelas eksperimen mencapai nilai KKM, (2) terdapat perbedaan yang signifikan antara kelas yang diajarkan dengan komik IPA dan kelas yang diajarkan dengan model konvensional, artinya hasil TPB bagian-bagian tumbuhan pada kelas eksperimen lebih baik daripada kelas kontrol. Perbedaan ini dapat dilihat dari $\mathbf{t}_{\text {hitung }}=\mathbf{8 , 4 7}>$ $\mathbf{t}_{\text {tabel }}=\mathbf{2 , 0 0}$ artinya prestasi belajar IPA siswa kelas eksperimen lebih baik dari prestasi belajar IPA kelas kontrol. Hal tersebut didukung dengan perolehan rata-rata prestasi belajar IPA siswa kelas eksperimen yaitu 81,52 yang lebih besar dari rata-rata prestasi belajar IPA siswa kelas kontrol yakni 57,52. (3) Hasil analisis uji peningkatan kelas eksperimen diperoleh nilai rata-rata yaitu 0,565 , artinya peningkatan prestasi belajar IPA siswa kelas eksperimen berada pada kategori sedang dan hasil analisis uji peningkatan kelas kontrol diperoleh nilai rata-rata yaitu 0,404 , artinya peningkatan prestasi belajar IPA siswa kelas kontrol berada pada kategori rendah.

\section{DAFTAR PUSTAKA}

Arikunto, Suharsimi. Prosedur Penelitian Suatu Pendekatan praktik. Jakarta: Rineka Cipata 
Arroio, A. 2011."Comics As A Narrative In Natural Science Education". Western AnatoliaJournal of Educational Sciences. 6(14), 93-98

Hariyanto. 2011. Sains untuk sekolah dasar kelas IV. Jakarta : Erlangga

Koesoemo, A.D. 2007. Pendidikan Karakter Strategi Mendidik Anak di Zaman Global. Jakarta: Gramedia.

Maharsi, I,. 2011. Komik Dunia Kreatif Tanpa Batas. Yogyakarta: Kata Buku

Pannen, P.\& Purwanto. 2011. Penulisan bahan Ajar. Jakarta: Pusat Antar Universitas untuk Peningkatan dan Pengembangan Aktivitas Intruksional Ditjen Dikti Dikdas.

Prastowo, A.2012. Panduan Kreatif Membuat Bahan Ajar Inovatif. Jogjakarta. DIVA Press

Purwanto, D., danYuliani. 2013. "Pengembangan Media Komik IPA Terpadu Tema Pencemaran Air Sebagai Media Pembelajaran untuk Siswa SMP Kelas VII". Jurnal Pendidikan Sains ePensa. Volume 01 (01), 71-76.

Rahayu, wahyuningsih. 2012 “ Pengembangan model Pembelajaran Komeks yang Bermuatan Nilai-Nilai Pendidikan Karakter aspek Membaca Intensif di kelas IV SD". Tesis. Semarang: Unnes

Rota, G. \& Izquierdo, J. 2013.“Comics As a Tool For Teaching Biotechnology In Primary
Schools". Electronic Journal of Biotechnology. 6(2), 85-89.

Santana, E.R. \& Arroio, A. 2011."Comics: A Tool For Teachers And Students In Teaching and Learning Science". Natural Science Education. 2(31), 49-59.

Song, Y; Heo,M \&Krumenaker, L. 2008. "Cartoon- An Alternative LearningAssesment". Science Scope.31(5), 16-21.

Sudjana N .2005. Dasar - Dasar Proses Belajar Mengajar. Bandung: SinarBaru.

Sudjana,N., \& Rivai, A. 2010. Media Pengajaaran "Penggunaan dan Pembuatannya”. Bandung: Sinar Baru Algesindo.

Sudjana, N. 2011.Penilaian Hasil Proses Belajar Mengajar. Bandung: Rosdakarya.

Sugiyono. 2010. Metode Penelitian Pendidikan Kuantitatif, Kualitatif, dan R\& D. Bandung: Alfabeta

Tatalovic, M. 2009. "Science Comics As Tools For Science Education and Communication: A Brief, Exploratory Study". Journal of Science Communication. 8(4), 117

Wahyuningsih, $\quad$ A.N. 2011. Pengembangan media komik bergambar materi sistem saraf untuk pembalajaran yang menggunakan Strategi PQ4R. Jurnal PenelitianPendidikan, Volume 1 No.2. Hal 102-110. 